\section{РАЗВИТИЕ МЕЖДУНАРОДНОГО СОТРУДНИЧЕСТВА В ДЕЯТЕЛЬНОСТИ УПОЛНОМОЧЕННОГО ПО ПРАВАМ ЧЕЛОВЕКА В РОССИЙСКОЙ ФЕДЕРАЦИИ}

\begin{abstract}
Аннотация. В статье рассматриваются вопросы развития международного сотрудничества как одного их ключевых направлений деятельности Уполномоченного по правам человека в Российской Федерации. Представлены особенности регулирования деятельности Уполномоченного, в том числе последние новеллы национального законодательства и международных стандартов в этой области. Особое внимание уделено направлениям и формам сотрудничества Уполномоченного с национальными правозащитными институтами иностранных государств, универсальными и региональными международными организациями, интеграционными объединениями омбудсменов. Приведены примеры взаимодействия Уполномоченного с ООН и Советом Европы на современном этапе. Освещена деятельность Уполномоченного по защите прав российских граждан и соотечественников, находящихся за рубежом. Представлена работа по развитию и укреплению «правозащитной дипломатии». Отражены вопросы становления и укрепления Евразийского альянса омбудсменов.

Предложены рекомендации по расширению компетенции Уполномоченного.

Ключевые слова: Уполномоченный по правам человека в Российской Федерации, права человека, национальные правозащитные учреждения, Евразийский альянс омбудсменов, ООН, Совет Европы, правозащитная дипломатия.
\end{abstract}

DOI: 10.17803/2311-5998.2021.80.4.085-095

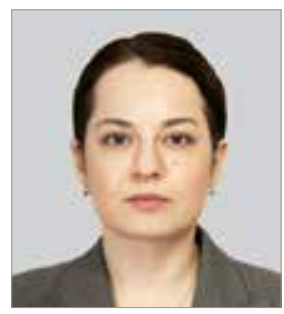

Ольга

Константиновна ГОНЧАРЕНКО, начальник отдела сотрудничества с международными организациями аппарата Уполномоченного по правам человека в Российской Федерации, соискатель кафедры международного права МГИМО (У) МИД России goncharenko_ok@bk.ru 119121, Россия, г. Москва, Смоленский 6-р, д. 19, стр. 2

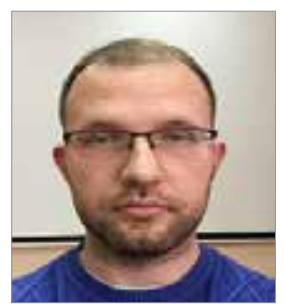

\footnotetext{
Андрей Олегович АХМЕТЗЯНОВ, главный специалистэксперт отдела сотрудничества с международными организациями аппарата Уполномоченного по правам человека в Российской Федерации axmed-91@mail.ru 119121, Россия, г. Москва, Смоленский б-р, д. 19, стр. 2

() О. К. Гончаренко,

А. О. Ахметзянов, 2021
} 
Head of International Multilateral Cooperation Division,

Office of the High Commissioner for Human Rights in the Russian Federation;

PhD student, Department of International Law, MGIMO

goncharenko_ok@bk.ru

119121, Russia, Moscow, Smolensky Boulevard, 19, str. 2

A. O. AKHMETZYANOV,

Chief Expert of International Multilateral Cooperation Division,

Office of the High Commissioner for Human Rights in the Russian Federation

Axmed-91@mail.ru

119121, Russia, Moscow, Smolensky Boulevard, 19, str. 2

\title{
THE PROMOTION OF INTERNATIONAL COOPERATION IN THE ACTIVITIES OF THE HIGH COMMISSIONER FOR HUMAN RIGHTS IN THE RUSSIAN FEDERATION
}

\begin{abstract}
The article addresses issues related to the development of international cooperation as one of the key areas of activity of the High Commissioner for Human Rights in the Russian Federation. The special features regulating the activities of the High Commissioner, including the novelty in the national legislation and international standards in this area have been presented.

Special attention has been given to the directions and forms of cooperation of the High Commissioner with national human rights institutions of foreign states, universal and regional international organizations, integration associations of ombudsmen. Examples of the interaction of the High Commissioner with the United Nations and the Council of Europe at the present stage have been provided. The efforts of the High Commissioner to protect the rights of the Russian citizens and compatriots living abroad have been highlighted. The article presents the development and strengthening of such concept as "human rights diplomacy". The aspects of the establishment and promotion of the Eurasian Ombudsman Alliance have been reflected.

In conclusion, the authors make recommendations on the extension of the competence of the High Commissioner.

Keywords: High Commissioner for Human Rights in the Russian Federation, human rights, National Human Rights Institutions, Eurasian Ombudsman Alliance, UN, Council of Europe, human rights diplomacy.
\end{abstract}

\section{Нормативно-правовая основа международной деятельности Уполномоченного по правам человека в Российской Федерации}

Должность Уполномоченного по правам человека в Российской Федерации (далее - Уполномоченный) была введена Конституцией России 1993 г. Деятельность Уполномоченного регулируется Федеральным конституционным законом 
от 26 фревраля 1997 г. № 1-ФКЗ «Об Уполномоченном по правам человека в Российской Федерации» ${ }^{1}$ (далее - ФКЗ № 1).

Согласно ч. 1 ст. 1 названного Федерального конституционного закона должность Уполномоченного учреждается в соответствии с Конституцией РФ (п. «е» ст. 103) в целях обеспечения гарантий государственной защиты прав и свобод граждан, их соблюдения и уважения государственными органами, органами местного самоуправления и должностными лицами. При этом средствами, указанными в ФКЗ № 1, Уполномоченный способствует восстановлению нарушенных прав, совершенствованию законодательства Российской Федерации о правах человека и гражданина и приведению его в соответствие с общепризнанными принципами и нормами международного права, развитию международного сотрудничества в области прав человека, правовому просвещению по вопросам прав и свобод человека, форм и методов их защиты.

Помимо Конституции РФ и ФКЗ № 1, правовые основы осуществления деятельности Уполномоченного регулируются более чем двумя десятками федеральных конституционных законов и федеральных законов, среди которых Федеральный закон от 25 июля 2002 г. № 115-Ф3 «О правовом положении иностранных граждан в Российской Федерации» ${ }^{2}$ (далее - Федеральный закон № 115-Ф3) и Федеральный закон от 15 июля 1995 г. № 101-Ф3 «О международных договорах Российской Федерации» ${ }^{3}$ (далее - Федеральный закон № 101-Ф3).

В соответствии со ст. 32.1-1 Федерального закона № 115-Ф3 Уполномоченный при осуществлении своих полномочий, в том числе при проверке жалоб, поступивших от иностранных граждан, вправе посещать центры временного размещения и места временного содержания лиц, ходатайствующих о признании беженцами либо вынужденными переселенцами или о предоставлении временного убежища на территории Российской Федерации, лиц, признанных беженцами либо вынужденными переселенцами или получивших временное убежище на территории Российской Федерации, а также специальные учреждения.

В соответствии со ст. 8 Федерального закона № 101-Ф3 рекомендации о заключении международных договоров Российской Федерации могут представляться Уполномоченным по правам человека в Российской Федерации по вопросам его ве́дения.

При осуществлении своей деятельности Уполномоченный руководствуется не только законодательством Российской Федерации, но и общепризнанными принципами и нормами международного права.

В настоящее время на универсальном и региональном международном уровне разработан и принят ряд принципиальных документов, закрепивших нормативные основы функционирования омбудсменов и национальных правозащитных учреждений. В этом контексте необходимо отметить Парижские принципы, касающиеся статуса национальных учреждений, занимающихся поощрением и защитой прав человека ${ }^{4}$, Венецианские принципы защиты и укрепления института омбудсмена,

1 С3 РФ. 1997. № 9. Ст. 1011 // Российская газета. 1997. № 43-44.

2 СЗ РФ. 2002. № 30. Ст. 3032.

3 С3 РФ. 1995. № 29. Ст. 2757.

4 Принципы, касающиеся статуса национальных учреждений, занимающихся поощрением и защитой прав человека (Парижские принципы), утверждены резолюцией 48/134

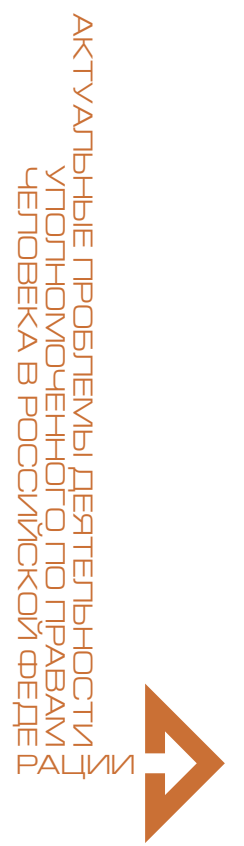


принятые Европейской комиссией за демократию через право в марте 2019 г. Рекомендацию Комитета министров Совета Европы «О совершенствовании института омбудсмена», принятую на 1357-м заседании 16 октября 2019 г. ${ }^{6}$, и Резолюцию A/RES/75/186 «Роль институтов омбудсмена и посредника в поощрении и защите прав человека, благого управления и верховенства права», принятую в ходе 75-й сессии Генеральной Ассамблеи ООН 16 декабря 2020 г7.

Помимо нормативных основ. эти документы содержат набор инструментов, который необходимо использовать национальным правозащитным учреждениям в области развития международного сотрудничества, а именно: поощрение соответствия национального законодательства принятым на себя государством международным обязательствам в сфере защиты прав человека; участие в подготовке органами государственной власти докладов о ситуации с правами человека в адрес соответствующих органов ООН и региональных организаций; представление альтернативных докладов в указанные структуры; сотрудничество с $\mathrm{OOH}$, региональными учреждениями и национальными учреждениями других стран, компетентными в вопросах поощрения и защиты прав человека; контроль за исполнением государством принятых на себя международных обязательств в области защиты прав человека.

С учетом прогрессивных наработок международного сообщества в области организации деятельности омбудсменов, международных норм мягкого права в этой области, в последние несколько лет Уполномоченным проводилась масштабная работа по их имплементации в российское законодательство, результатом которой стало принятие всеобъемлющего и комплексного законодательства об уполномоченных по правам человека в Российской Федерации, которое гарантирует федеральному и региональным уполномоченным по правам человека

Генеральной Ассамблеи ООН от 20 декабря 1993 г. // Официальный портал Организации Объединенных Наций. URL: https://www.un.org/ru/documents/decl_conv/conventions/paris. shtml (дата обращения: 26 января 2021 г.).

5 Принципы защиты и укрепления института омбудсмена (Венецианские принципы), приняты Венецианской комиссией на 118-й пленарной сессии (г. Венеция, 15-16 марта 2019 г.), одобрены Комитетом министров Совета Европы на 1345-м заседании заместителей министров, Парламентской ассамблеей Совета Европы, Резолюцией 2301(2019) от 2 октября 2019 г., Конгрессом местных и региональных властей Совета Европы, Резолюцией 451(2019) от 30 октября 2019 г. // Официальный портал Совета Европы. URL: https:// www.venice.coe.int/webforms/documents/default.aspx?pdffile=CDL-AD(2019)005-rus (дата обращения:: 26 января 2021 г.).

6 Recommendation $\mathrm{CM} / \operatorname{Rec}(2019) 6$ of the Committee of Ministers to member States on the development of the Ombudsman institution, adopted by the Committee of Ministers on 16 October 2019 at the 1357th meeting of the Ministers' Deputies// Официальный портал Совета Европы. URL: https://rm.coe.int/090000168098392f (дата обращения: 27 января 2021 г.).

7 Резолюция, принятая Генеральной Ассамблеей ООН 16 декабря 2020 г., по докладу Третьего комитета (A/75/478/Add.2, пункт 89) 75/186 «Роль институтов омбудсмена и посредника в поощрении и защите прав человека, благого управления и верховенства права» // Официальный портал OOH. URL: https://undocs.org/ru/A/RES/75/186 (дата обращения: 27 января 2021 г.). 
полную независимость в реализации своих полномочий, в частности Федерального закона от 18 марта 2020 г. № 48-Ф3 «Об уполномоченных по правам человека в субъектах Российской Федерации» 8 .

Пунктом 4 статьи 1 указанного Закона впервые в истории российского правозащитного сообщества закреплено право на участие региональных уполномоченных в развитии международного сотрудничества в области прав человека.

\section{Основные направления международной деятельности Уполномоченного по правам человека в Российской Федерации}

Рассмотренная нормативно-правовая база международной деятельности Уполномоченного определяет ее основные направления:

- защита прав граждан Российской Федерации и российских соотечественников, попавших в сложную жизненную ситуацию за рубежом;

- защита прав иностранных граждан, находящихся на территории Российской Федерации;

- сотрудничество с национальными правозащитными учреждениями иностранных государств;

- взаимодействие с международными организациями и интеграционными объединениями национальных правозащитных учреждений;

- совершенствование законодательства Российской Федерации о правах человека и гражданина и приведение его в соответствие с общепризнанными принципами и нормами международного права.

Согласно ст. 61 Конституции РФ, «Российская Федерация гарантирует своим гражданам защиту и покровительство за ее пределами» ${ }^{9}$. Соответствующие положения также содержатся в Федеральном законе от 31 мая 2002 г. № 62-Ф3 «О гражданстве Российской Федерации» (ст. 7), Федеральном законе от 24 мая 1999 г. № 99-Ф3 «О государственной политике Российской Федерации в отношении соотечественников за рубежом» (ст. 15), Концепции внешней политики Российской Федерации, утвержденной Указом Президента РФ от 30 ноября 2016 г. № 640, а также в Указе Президента РФ от 7 мая 2012 г. № 605 «О мерах по реализации внешнеполитического курса Российской Федерации».

Следуя этим положениям, большое внимание в своей работе Уполномоченный уделяет защите прав российских граждан и соотечественников, находящихся на территории иностранных государств. Такая деятельность ведется как путем рассмотрения отдельных правозащитных кейсов, так и в рамках поиска решений системных проблем.

За последние 4 года наметилась тенденция увеличения количества обращений, поступающих к Уполномоченному из-за рубежа. Если в 2017 г. их число составило 687 заявлений, то в 2020 г. оно возросло до 1 100. Основные вопросы,

8 СЗ РФ. 2002. № 12. Ст. 1640.

9 Конституция Российской Федерации (принята всенародным голосованием 12 декабря 1993 г. с изменениями, одобренными в ходе общероссийского голосования 1 июля 2020 г.) // URL: http://www.pravo.gov.ru (дата обращения: 26 января 2021 г.). 
которые поднимают российские граждане, касаются оказания содействия в возвращении на Родину; защиты прав в рамках уголовного судопроизводства на территории иностранных государств; улучшения условий содержания в местах лишения свободы; защиты прав по семейным делам; сохранения русского языка и культуры; решения вопросов социального характера.

В зависимости от характера и тематики полученных обращений Уполномоченный использует определенный (но не исчерпывающий) набор механизмов для оказания содействия в восстановлении нарушенных прав, среди которых: направление запросов в профильные органы государственной власти Российской Федерации; обращение в адрес национальных правозащитных институтов зарубежных стран; при отсутствии в государстве национального правозащитного института или омбудсмена - обращение в адрес органов государственной власти иностранных государств; обращение в адрес международных межправительственных/неправительственных организаций; разъяснение заявителю средств, которые тот вправе использовать для защиты своих прав и свобод.

К сожалению, в последнее время на повестке дня все чаще возникают вопросы политического характера, порождающие двойные стандарты в сфере защиты прав человека, а также лишающие наших граждан возможности в полной мере пользоваться своими правами. Речь идет об ограничениях русскоязычного национального меньшинства, испытывающего системное ограничение права на образование и культурное самоопределение в Прибалтике и на Украине; героизации неонацизма и неофашизма; ущемлении прав жителей Крымского полуострова; воспрепятствовании профессиональной деятельности российских журналистов за рубежом; случаях применения бесчеловечного обращения с задержанными и заключенными, жестокости и насилия.

Руководствуясь принципами гуманизма, исходя из абсолютной ценности человеческой жизни, наличия неотъемлемых прав и свобод у каждого человека и гражданина, стремясь к совершенствованию механизмов защиты прав человека и укреплению демократических основ своих государств, в поисках решения указанных проблем Уполномоченный зачастую использует инструменты двустороннего взаимодействия с коллегами из иностранных государств путем совместного рассмотрения обращений, проведения регулярных консультаций, приемов граждан, научных исследований, организации работы по правовому просвещению населения, проведения различных тематических мероприятий.

Нормативную основу такого взаимодействия, осуществляемого на принципах взаимности и синхронности, составляют соглашения (меморандумы) о сотрудничестве с зарубежными коллегами. В настоящее время Уполномоченным заключены и действуют 16 таких соглашений с омбудсменами или национальными правозащитными институтами 15 государств: Азербайджана, Армении, Боснии и Герцеговины, Греции, Ирана, Казахстана, Камбоджи, Киргизии, Приднестровья, Монголии, Сербии, Таджикистана, Турции, Узбекистана и Украины.

Отметим, что соглашения о сотрудничестве не подпадают под критерии международного договора или межведомственного соглашения в понимании Федерального закона от 15 июля 1995 г. № 101-Ф3 «О международных договорах Российской Федерации» или Венской конвенции о праве международных договоров 1969 г. Они являются примером использования мягкого права, нацеленного на 
формализацию двусторонних взаимоотношений национальных правозащитных учреждений, функционирующих в различных государствах, но имеющих одну общую цель - оказание помощи людям. Можно сказать, что этот инструментарий лег в основу такого понятия, как «правозащитная дипломатия».

Уполномоченный, развивая, с одной стороны, двустороннее международное сотрудничество, с другой стороны, стремится к расширению многостороннего международного взаимодействия с межправительственными правозащитными организациями универсального и регионального уровня (OOH, Совет Европы, ОБСЕ) и интеграционными сообществами омбудсменов в целях повышения гарантий защиты прав человека, восстановления нарушенных прав граждан, продвижения российских правозащитных достижений и обмена лучшими практиками деятельности.

В качестве основных форм такого взаимодействия можно назвать представление информации о ситуации с правами человека в Российской Федерации; участие в совместных проектах; проведение рабочих встреч на экспертном и высшем уровнях; организацию совместных мероприятий; имплементацию международных стандартов в национальное законодательство; работу по отдельным правозащитным кейсам.

Важным направлением деятельности является обобщение, анализ и представление позиции Уполномоченного по вопросам выполнения Российской Федерацией международных обязательств, взятых на себя в сфере защиты прав человека. Так, только за последние 5 лет Уполномоченным представлено семь альтернативных докладов в договорные органы по правам человека системы $\mathrm{OOH}$ : Комитет по правам человека, Комитет по ликвидации дискриминации в отношении женщин, Комитет против пыток, Комитет по правам инвалидов, Комитет по экономическим, социальным и культурным правам, Комитет по ликвидации расовой дискриминации.

В октябре 2017 г. Уполномоченным был направлен Параллельный доклад Рабочей группе Периодического обзора Совета по правам человека ООН в рамках прохождения третьего цикла Универсального периодического обзора Российской Федерацией, который для нашей страны успешно завершился в 2018 г. В этих докладах освещается деятельность Уполномоченного по данным направлениям, приводится статистика по поступившим жалобам, отражены наиболее актуальные проблемы и предложены пути их решения ${ }^{10}$.

В рамках мониторинга реализации решений Европейского Суда по правам человека на национальном уровне и в соответствии с действующими Правилами Комитета министров Совета Европы Уполномоченный имеет возможность направлять заключения в адрес Суда относительно исполнения принятых им решений ${ }^{11}$.

10 Гончаренко О. К. Преимущества статуса А для Уполномоченного по правам человека в Российской Федерации (обзор деятельности) // Проблемы защиты прав человека на евразийском пространстве: обмен лучшими практиками омбудсменов : материалы II Международной научно-практической конференции (Москва, 5 декабря 2017 г.) / под ред. Т. Н. Москальковой. М., 2018. С. 209-216.

${ }_{11}$ Rules of the Committee of Ministers for the supervision of the execution of judgments and of the terms of friendly settlements, adopted by the Committee of Ministers on 10 May 2006 at

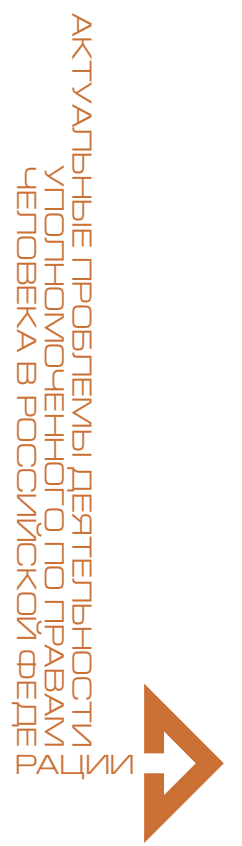


Впервые в истории российского правозащитного института в Комитет министров Совета Европы было направлено заключение по делу «Свинаренко и Сляднев против Российской Федерации», в котором выражена позиция Уполномоченного относительно необходимости изменения процедуры содержания граждан в железных клетках в залах судебных заседаний ${ }^{12}$.

Особое внимание в своей деятельности Уполномоченный уделяет реализации совместных с международными организациями проектов. По линии ООН это обучающие семинары в рамках стажировки русскоязычных представителей коренных народов, учебная Магистерская программа по правам человека, семинары-тренинги для региональных уполномоченных по правам человека; по линии Совета Европы - сотрудничество в области реализации Национальной стратегии действий Российской Федерации в интересах женщин на 2017-2022 годы, ОНК - новое поколение и др. Более подробно вопросы взаимодействия с Советом Европы представлены в отдельной статье Уполномоченного ${ }^{13}$.

При осуществлении международного сотрудничества Уполномоченный также проводит масштабную работу в рамках интеграционных объединений омбудсменов универсального и регионального уровня, среди которых Евразийский альянс омбудсменов, Глобальный альянс национальных правозащитных учреждений; его Европейская сеть; Международный и Европейский институты омбудсменов. На таких площадках удается делиться прогрессивными правозащитными российскими наработками, знакомиться с международным опытом деятельности и имплементировать его в национальное законодательство, оперативно и без лишних бюрократических проволочек оказывать помощь тем, кто в ней более всего нуждается.

В 2017 г. по инициативе Уполномоченного и при поддержке омбудсменов Армении и Киргизии в г. Москве учрежден Евразийский альянс омбудсменов (далее - EAO, Альянс), который действует на основе уставного документа Меморандума ${ }^{14}$.

Согласно его положениям, основными задачами Альянса являются распространение знаний о способах защиты гражданских и индивидуальных прав, сотрудничество в сфере обеспечения их защиты, осуществление международного сотрудничества Альянса с соответствующими международными и региональными

the 964th meeting of the Ministers' Deputies and amended on 18 January 2017 at the 1275th meeting of the Ministers' Deputies // Official Portal of the Council of Europe. URL: https:// rm.coe.int/16806eebf0 (дата обращения: 26 января 2021 г.).

12 Rule 9.3 Communication from a NHRI (28/03/2019) inthecase of Svinarenko and Slyadnev v. Russian Federation (Application No. 32541/08) // Официальный сайт Совета Европы. URL: https://search.coe.int/cm/Pages/result_details.aspx?Objectld=090000168093dd18 (дата обращения: 18.01.2021).

${ }^{13}$ Москалькова Т. Н. Взаимодействие Уполномоченного по правам человека в Российской Федерации и Совета Европы: история, достижения, перспективы // Международная жизнь. 2021. № 2.

${ }^{14}$ Меморандум о создании Евразийского альянса омбудсменов от 5 декабря 2017 г. // Официальный портал Евразийского альянса омбудсменов. URL: https://eoalliance.org/ information/objectives.php (дата обращения: 26 января 2021 г.). 
организациями, зарубежными омбудсменами и их ассоциациями. Взаимодействие между его членами может осуществляться в формах обмена информацией, создания совместных рабочих групп, поддержки и стимулирования проведения исследований в области прав человека, совместных визитов. Юридическая природа Меморандума аналогична рассмотренным выше двухсторонним соглашениям о сотрудничестве между национальными правозащитными учреждениями.

В настоящее время членами ЕАО являются восемь национальных правозащитных учреждений Армении, Ирана, Казахстана, Киргизии, Монголии, России, Сербии, Таджикистана. Альянс является первым в истории объединением, который консолидирует усилия государственных правозащитников Европы и Азии.

За период работы этого интеграционного сообщества проведено 5 пленарных заседаний, в ходе которых состоялся обстоятельный обмен мнениями в сфере защиты прав человека, обсуждались актуальные вопросы гуманитарного и правового характера.

\section{Выводы и рекомендации}

Как показывает практика международной деятельности Уполномоченного, сфера его компетенции довольно широка. Еще более полной она представляется при анализе всех полномочий, которыми Уполномоченный наделен в соответствии с ФКЗ № 1.

Вместе с тем именно двустороннее и многостороннее международное сотрудничество Уполномоченного позволяет выявить лучшие практики правозащитной работы омбудсменов зарубежных государств и прийти к выводу о возможности расширения компетенции российского Уполномоченного. На этих вопросах в своих научных работах подробно останавливались В. В. Черников ${ }^{15}$, Д. С. Фесько ${ }^{16}$ и сама Уполномоченный Т. Н. Москалькова ${ }^{17}$.

Например, омбудсмены ряда иностранных государств имеют право рассматривать обращения не только в отношении органов государственной власти и должностных лиц, но и организаций негосударственного сектора. Конечно, в силу специфики своей деятельности Уполномоченный принимает жалобы на работу образовательных и медицинских учреждений, которые особо участились в период борьбы с коронавирусной инфекцией COVID-19. Вместе с тем эта практика выходит за рамки мандата Уполномоченного и требует законодательного урегулирования.

15 Черников В. В. Законодательство об Уполномоченном по правам человека в Российской Федерации нуждается в обновлении // Проблемы защиты прав человека на евразийском пространстве: обмен лучшими практиками омбудсменов. С. 275-282.

16 Фесько Д. С. Внесудебная защита прав граждан при проведении государственного контроля (надзора) и место в ней уполномоченных по правам человека // Проблемы защиты прав человека на евразийском пространстве: обмен лучшими практиками омбудсменов. C. 267-274.

17 Москалькова Т. Н. Институт уполномоченных по правам человека в государственном механизме России // Административное право и процесс. 2018. № 12. С. 52-59. 
Также интерес представляет наделение национальных правозащитных институтов функциями национального превентивного механизма, благодаря чему сами омбудсмены и их представители имеют право посещать места принудительного содержания в любое время без предупреждений. По современному российскому законодательству такое право имеет лишь Уполномоченный.

В целях эффективной реализации деятельности Уполномоченного большое значение имеют вопросы наличия соответствующих гарантий независимости и функционального иммунитета не только у первого лица, но и у сотрудников его аппарата.

Подводя итог, необходимо отметить, что международное направление деятельности Уполномоченного по правам человека в Российской Федерации является многосторонним и комплексным явлением, основанным на нормах и принципах национального и международного права.

В ходе своей практической работы по развитию и укреплению «правозащитной дипломатии» институтом Уполномоченного был выработан уникальный механизм формализации взаимоотношений между национальными правозащитными учреждениями в виде «мягких» норм, таких как соглашения о сотрудничестве или меморандумы о взаимопонимании.

В целом в настоящее время Уполномоченный вовлечен во все международные процессы, отстаивая лучшие интересы страны на различных универсальных и региональных площадках и оставаясь неизменным партнером международных организаций, интеграционных объединений омбудсменов и зарубежных коллег на правозащитном направлении. Такая самоотверженная деятельность в полной мере свидетельствует о повышении гарантий защиты прав человека в России и увеличении числа восстановленных прав граждан, в том числе и благодаря применению передового международного правозащитного опыта.

\section{БИБЛИОГРАФИЯ}

1. Гончаренко О. К. Преимущества статуса А для Уполномоченного по правам человека в Российской Федерации (обзор деятельности) // Проблемы защиты прав человека на евразийском пространстве: обмен лучшими практиками омбудсменов : материалы II Международной научно-практической конференции, посвященной 70-летию принятия Всеобщей декларации прав человека и 25-летию принятия Конституции Российской Федерации (Москва, 5 декабря 2017 г.) / под ред. Т. Н. Москальковой. - М., 2018. - С. 209-216.

2. Москалькова Т. Н. Взаимодействие Уполномоченного по правам человека в Российской Федерации и Совета Европы: история, достижения, перспективы // Международная жизнь. - 2021. — № 2.

3. Москалькова Т. Н. Институт уполномоченных по правам человека в государственном механизме России // Административное право и процесс. - 2018. № 12. - С. 52-59.

4. Фесько Д. С. Внесудебная защита прав граждан при проведении государственного контроля (надзора) и место в ней уполномоченных по правам человека // Проблемы защиты прав человека на евразийском пространстве: 
обмен лучшими практиками омбудсменов : материалы II Международной научно-практической конференции, посвященной 70-летию принятия Всеобщей декларации прав человека и 25-летию принятия Конституции Российской Федерации (Москва, 5 декабря 2017 г.) / под ред. Т. Н. Москальковой. 2018. - С. 267-274.

5. Черников В. В. Законодательство об Уполномоченном по правам человека в Российской Федерации нуждается в обновлении // Проблемы защиты прав человека на евразийском пространстве: обмен лучшими практиками омбудсменов : материалы II Международной научно-практической конференции, посвященной 70-летию принятия Всеобщей декларации прав человека и 25-летию принятия Конституции Российской Федерации (Москва, 5 декабря 2017 г.) / под ред. Т. Н. Москальковой. - М., 2018. — С. 275-282. 